\title{
RECOGNITION OF THE CUSTOMARY LAND LAW IN THE CONSTITUTION OF INDONESIA AND MALAYSIA
}

\author{
Datu Bua Napoh \\ Faculty of law, Brawijaya University \\ Email: datunapoh@gmail.com
}

\begin{abstract}
Recognition of customary land law is very important for indigenous peoples in their daily lives to protect the existence of the preservation of customary law itself, because this is a traditional lands where they carry out their daily routines and develop their traditional habits which categorized as unique and different from other areas. In Indonesia, the customary land law is recognized as long as it really exists and does not contradict the higher principle and state law. We can see it in article 3 UUPA in 1960, and article 18b paragraph 1945 Constitution of the Republic of Indonesia; while in Malaysia, customary land law is also protected in the Constitution of Malaysia Certificate 134, Original Certificate in 1954. Moreover, the recognition of indigenous land has also been described by the "UN Declaration on the Rights of Indigenous Peoples in articles 8, 10, 26, 29, 30, 32", the UN explains how they give great recognition of the law of customary land to provide rights and obligations to society custom to protect the existence and preservation of the traditions that they get from their ancestors.
\end{abstract}

Keywords: customary, law, constitution, Malaysian Law

\section{INTRODUCTION}

Facing this modern era, there are so many problems faced by the community of the world, from the economic, social, education and culture aspect. Especially in Indonesia and Malaysia, where both countries are classified as developing countries, according to the World Economic Report of the International Monetary Fund,
April $2010^{1}$. In this article, we will discuss about the impact of culture by seeing the presence of customary land law as a very important element, especially if we look at the demands for developing countries are trying to pursue the achievement of developed countries. This is what has been faced by Indonesia and Malaysia because of limited income per capita which is

\footnotetext{
1 Http://id.wikipedia.org/wiki/negara_berkembang\#c ite_note-8 retrieved on October 23, 201410.18 pm
} 
categorized as very low. In addition, the development of building construction and facilities and also the infrastructure of the private building or government-owned land that is increasing from year to year requires large amounts of land. In fact, we know that soil is material that is consistent and can not be renewed. Moreover, in Indonesia and Malaysia who know the law of customary land has been owned and managed by indigenous peoples as part of the heritage of their ancestors, and they must continue to ensure its existence and continuity. Of course we know that indigenous land is a place where they perform and preserve their own customary laws. That is why we must not forget the past. I said that because the past reminds us that there is a land that has been owned and is bequeathed to them as grace from the God. They have been born in the region that we should give an honor and great appreciation because they were here before the unitary state is formed. Thus, it needs a policy to mediate between human needs of a land and the land itself in certain areas so that it will create the rights and obligations to the person who uses the land and this is what is in customary land.

Customary land is part of customary law which is made up of local culture from predecessors who passed orally to their descendants. For the sake of it, we need to know the definition of customary law first. Customary Law (in Indonesia, its called hukum adat) is derived from Arabic word " $h u k$ 'm" that literally means regulation, while "adat" means tradition or pattern of behavior of a community. Therefore, hukum adat is a tradition. Christian Snouck Hurgronje is the first person to introduce the term of hukum adat or customary laws in his book De Atjehers (The People of Aceh) in 1894, which was written in Dutch, AdatRecht. The book is written based on the result of research that he conducted in Aceh from 1891 to 1892 for the benefits of Dutch colonials. The term of customary law was then popularized by Cornelis Van Vollenhoven in his book "Het Adat-Recht van Nederlandsch Indie (Th Customs of Indonesia). According to Cornelis Van Vollenhoven, definition of customary law proposed by the scholars is "compilation of regulations related to behavior and attitude that indigenous people and foreigners should follow in a community, because in one hand it entails sanction or penalty, it consists of local laws, and in other hand it is not a subject of codification because it is tradition. According to J.H.P. Bellefroid, customary 
law is a group of living rules that even though it is not institutionalized by the authorities, it is regarded with high respect by the people, believing that the rules are intended as laws ${ }^{2}$. Hardjito Notopuro claimed that "customary law is unwritten law or custom which is characterized by the fact that it is regarded by people as life principle in establishing justice and community welfare, and it is based on kinship $^{3}$. From definitions set by three experts, it can be concluded that customary laws are traditions and rules, unwritten, but observed by the indigenous people as principles that they believe in.

According to C. Van Vollenhoven, he mentions six characteristics of indigenous rights, they are alliance and its members have the right to take advantage of the land, the harvest of all the things that grow and live in this land. The sixth characteristics of indigenous rights are mentioned as follows: ${ }^{4}$

1. Individual rights are covered by all alliance rights.

${ }^{2}$ Soerojo Wignojodipoero, Introduction and Principles of Adat Law, Haji Masagung, Jakarta, 1983, page 14

${ }^{3}$ Hardjito Notopuro, About adat law, definition and limitation in national law, National Law Magazine No. 4, Jakarta, 1969, page 49

${ }^{4}$ Wulansari C. Dewi,. Adat Law Indonesia An

Introduction. Reflika Aditama,Bandung. 2012, page. 81
2. The leader of the alliance will be decisive for his tribe and the use of certain land areas, also nominated for the benefit of the general public and for this land is not allowed for individual rights.

3. The foreigner who wants to take the product of this customary land must be asking permission from the alliance first and pay recognition money, and after the harvest they must pay the rent.

4. The Alliance responsible for everything that happens in the adat land.

5. Prohibited from alienating the customary land there. Both the alliance and its members are not allowed to make absolute decisions on land, so the land authorities removed.

From the explanation above about the rights of indigenous peoples to their traditional lands, we now indirectly understand that implementing these rights should have customary land law as a realization of the rule itself. Therefore, we need to see whether these two countries are 
still able to maintain the existence of the law of customary land as part of the heritage, even under the territorial sovereignty of Malaysia and Indonesia, each country should have a national law governing the law of the land law that puts equally to the citizen of the country. In Malaysia and Indonesia, there is a law that is rarely considered customary land from customary law in each country. It will be a big challenge for Indonesia and Malaysia to follow a different system, but it has indigenous people to see their country as the needs of developing countries to catch up with developed countries so that they will not be overlooked from the eyes of the World. Furthermore, both countries have an obligation to protect the interests of indigenous peoples.

\section{METHODE OF RESEARCH}

This paper uses juridical-normative method, including reviewing and analyzing the rules of Indonesian and Malaysian law concerning customary law, as well conducting a comprehensive analysis of Indonesian and Malaysian Law.

The approach in this paper is the Statute and comparative approach, which in this research will explore the comparison of law and constitution between Indonesia and Malaysia.

\section{RESULT AND DISCUSSION}

\section{A. Customary Land Law in Malaysia}

Customary land law is respected at the highest level in Malaysia, especially in Negeri Sembilan, where some areas there to uphold and enforce firmly to Perpatih tradition. Then, the management of customary land law in Negeri Sembilan adapted to customary law in Perpatih tradition in Malaysia because customary law is divided into two parts, namely Perpatih customary law and Temenggung customary law.

a. Perpatih Adat Law is a habitual and behavioral pattern of the community that hold on tight into Perpatih tradition which is brought in by Dato'Perpatih Nan Sebatang who came from Minangkabau, Tanah Tinggi, Padang, Sumatra to be exact, in the seventeenth century in Tanah Melayu. It is dedicated in Negeri Sembilan, Naning, and Alor Gajah, in which case this Perpatih customary law could be described as a complete rules for organizing most 
aspects of Minangkabau society's life, they are as follows:

1) Safety

2) Security

3) Harmony

4) Political stability

These four aspects are arranged in customary law system of Perpatih. In addition, the lives of people in the area are included in customary law Perpatih is matrilineal, where women have a major position in society. Because only women who will inherit, there is only one woman who inherited the wealth of parents and their children will follow their parents and their children will follow the mother's ethnicity, in other words, women hold the highest maternal words of other women is the highest status of securities at this tribe. This is also applied in Padang, Sumatera. The characteristics that showed the matrilineality system is in the form of below:

a) The Wealth Distribution, in this adat, inherit wealth will be be passed from mother to her daughter and if she does not have any daughter, it will be passed to her sister or the daughter of her sister or granddaughter of her sister. This happens because at this tribes, men prefer to wander to earn money so that women who are left behind should be able to provide for themselves. In addition, wealth not for an individual but for a family so that it cannot be sold to other families except for the certain reason.

b) Marriage, in Perpatih customary law, is exogamous marriage, which is not allowed to marry the same tribes because it is believed to still have blood relations. Along with the rule, the husband will follow in his wife's family after marriage and will not be allowed to marry the other woman from the same tribe with his wife. If the wife passed away, the children will be handed over to the wife's family because the husband is considered not having the right of the children.

c) Government system, the government policy which is practiced by Perpatih customary law is more democratic because the power is distributed equally from the top until the bottom arrangement. The leader is elected by 
all the people from the upper to the lower class.

d) Condemnation, in Perpatih customary law, procedure of awarding a penalty to the guilty person more leads to feelings, because they believe the person who made the mistake will change for the better and penalties aimed at reforming conditions, not impose penalties on the basis of suspicion. People who can put the death penalty is only the supreme authority, or the king.

e) The tribe, in Perpatih customary law only knows 12 tribes; they are Biduanda, Batu Hampar, PayaKumbuh, Mungkal, Tiga Nenek, Seri Melenggang, Seri Lemak, Batu Belang, Tanah Datar, Tiga Batu, Anak Aceh, and Anak Malaka. Among this tribe distribution, the family bond in the tribe is very tight and strong.

b. Temenggung Customary Law is customary law that applied in almost all the region across Malaysia except in Negeri Sembilan. This customary law is brought to Malaysia by Dato' Ketemenggungan (step brother of
Dato' Perpatih) who also came from Sumatera. This customary law most practiced by Malay Sultanate of Malacca and then inherited to the other Malay lands. The aspects that is given priority to be arranged in Temenggungan adat law are:

- Criminal Law

- The Inheritance Wealth Law

- Constitutional Law

The characteristic of the
Temanggung customary law is patrilineal, where men more prominent in this tradition because considered as the successor of the family, at the same level to Faraid law (Islamic inheritance law) which stated that men are the leader of the family, so the boys will get the inherit wealth from his father. The features that can be seen from Temenggung adat are:

1) The Wealth Distribution, the property will be passed to men generation because considered as the leader of the family, where the property that is owned is for individual who eventually will be charged for the tax which is given to the 
government of that region or country. The wealth is entirely the property of everyone.

2) Marriage, in Temenggung tradition, can be done with anyone provided, that does not violate the law of Islam and if they married, the wife will follow the husband's family because he is the leader of the family.

3) The government system, in this tradition, the system of government is autocracy where the absolute power is in the highest authority or the king. The king is the symbol of a country's sovereignty, the chief of religion and the administration. The kingship has been handed down to their descendants by successive.

4) Condemnation, the punishment given to the guilty person is punitive, has a beneficial effect of wary and reminded to others to do not make the same mistake. The punishment was handed down to someone by the status of that person. If the position in community is important, the punishment will be more lightweight than those who have the lower status than him, and to bring down the punishment for someone who needed the strong evidence first.

5) Tribal, in this adat does not employ the system tribe classification.

The explanation of customary law above shows how the two customary law is applied in Malaysia, we can find out how the application of customary land law in Malaysia. We know that people have to follow the customary law of the legal division of wealth, so the customary land law in Malaysia is divided into two, Perpatih and Temenggung customary law. Due to customary land law are part of customary law, so that the system used to administer customary law depends on that which applies in that area. In this modern era, customary law will be difficult to run is Perpatih customary law; because ownership does not have the right to an individual but to the family so that the management shall be in accordance with the approval of a large family and not being sold. Of course, this is 
very influential in the modern era because technological development and the increasing needs in making buildings and infrastructure facilities, land law customary in this tradition will block, but on the other hand will protect the ownership of that land so their descendant who holds firmly to this tradition would not be afraid to lose their land.

\section{B. Adat Land Law in Indonesia}

In Indonesia, the customary land law also follows the law that occurred in the local area. According to Cornelis van Vollenhoven who was the first launcherof this idea, he lift up the Archipelago according to customary law which can be divided into 23 indigenous environment, as follows: Aceh, Gayo and Batak, Nias and the surrounding area, Minangkabau, Mentawai, South Sumatra, Enggano, Melayu, Bangka Belitung, Kalimantan (Dayak), Sangihe-Talaud, Gorontalo, Toraja, South Sulawesi (Bugis/Makassar), North Maluku, Ambon, South-East Maluku, Papua, West Nusa Tenggara and Timor, Bali and Lombok, Java and Madura (Java Coasts), Java Mataraman, West Java (Sundanese). These regions have the various diversity of customary law so the customary land law follows these 23 traditions. The role of government is very crucial here as the mediator to anticipate the disagreement of indigeneous community which may lead to conflict. Based on customary law in Indonesia, there are 2 (two) various rights that arose of the ground, they are:

- The alliance, right which is owned, controlled, used, enjoyed, organized by a group of people lived in a certain area who called as law society (law alliance). Meaning, this alliance accurately described as indigenous rights, to become a true master, more, precise assembly is customary rights are often called, are Pertuan right, ancient, customary rights, or beschikingsrecht.

- Individual rights, the right which is owned, controlled, used, enjoyed, organized by a member of certain alliance.

By customary law of UUPA 1960, made on the basis of customary law and indigenous rights is one of the customary laws and institutions developed in the social function of land rights. Article 5 of UUPA states that "Agrarian Law were applied to the earth, water and space is the 
law of customary land, as long as it does not conflict with national interests and the state, based on the nation's unity, Indonesia's socialism as well as the rules stated in this law, and the applicable law, all apply the elements that rely on religious law. "5 From this article we can see how customary law in Indonesia is the highest priority if we want the land management, and if the land is located in the area of indigenous peoples.

\section{Malaysia's and Indonesia's Constitution in Protecting Customary Land LaW}

a. Malaysia's constitution in protecting their adat land law

Malaysia is the country that follows The legal of Anglo-Saxon (Common Law), it is a legal system that is based on jurisdiction law. Source of law in the legal system is adjudication. In the legal system, the role given to the judges is enormous. . Therefore, to know how the government of Malaysia protects the adat land law, we can see in the UNDANG-UNDANG MALAYSIA CETAKAN SEMULA Akta

\footnotetext{
${ }^{5}$ A.P. Parlindungan; Comments about the Legal Regulations Agrarian goods; Mandar Madju; Bandung, 1998, page 56.
}

134 AKTA ORANG ASLI 1954. In addition, as a country that follows the legal anglo-saxons, so I will present few cases that have been sentenced by the court:

1. Pedik bin Busu and others VS Yang Dipertua Majlis Daerah Gua Musang and others ${ }^{6}$

HIGH COURT (KOTA BHARU)

MOHD AZMAN HUSIN H

SUIT NO 24-24- 2007

29 October 2009

The plaintiffs owned a customary land at Kampung Jias, Rancangan Penempatan Semula, Kawasan Kuala Betis, Gua Musang ('the land'). The plaintiffs built a religious house for the Christian. The second defendant served the first notice to the plaintiffs for the building of the religious house to be stopped and to subsequently demolish the same within two weeks. The plaintiffs received two more notices from the second defendant on 19 April 2007 and 24 May 2007 directing the building on the land be demo-lished within 30 days. On 4 June 2007, the first defendant together with

\footnotetext{
${ }^{6}$ Malayan Law Journal Reports/2010/Volume 5/Pedik bin Busu dan lain-lain Yang Dipertua Majlis Daerah Gua Musang dan lain-lain - [2010] 5 MLJ 849 - 29 October 2009.
} 
the police and RELA had demolished the religious house

5 MLJ 849 at 851

Further, the plaintiffs filed an original summons in encl 1 for declaratory orders, inter alia, (i) the plaintiffs were entitled to practice the religion of their choice under the Malaysian Constitution and thus entitled to build the religious house on the land; (ii) the notices under s 425 of the National Land Code ('NLC') issued by the second defendant against the plaintiffs were void as it contravened the Federal Constitution ('the Constitution') and the Aboriginal Peoples Act 1954 ('the 1954 Act'); (iii) the first and second defendants' action of demolishing the religious house amounted to a trespass. The High Court decided, inter alia, that: the Street, Drainage and Building Act 1974 ('the Act') was inclusive and outweighed the 1954 Act, hence the first defendant has the power to demolish a building which is built within the jurisdiction of the first defendant if the building does not fulfill the requirement stated under the law; the building of the religious house was allowed under art 11(3)(c) of the
Constitution, but the plaintiffs had not made the application for approval of the building of the religious house; the first defendant did not comply with the notices served on the plaintiffs within 30 days when the religious house was demolished before the expiration of the 30 days notice.

Held, allowing the application:

(1) The ownership of the land by the plaintiffs was valid, although the land was not a customary land and the document of title was yet to be issued to them (see para 13 (a)).

(2) The plaintiffs were entitled to practice the religion of their choice and could build the religious house although it was not their custom. However, the building of the religious house ought to comply with the requirements of law especially the Act in view of the gazetting of the land area and had been stated to be under the supervision of Majlis Daerah Gua Musang. The applica-tion to build the religious house 
must be presented to the first defendant. Thus, the building of the religious house was not valid as the Act had not been complied with (see para 13(b)).

(3) The notice under s 425 of the NLC could be issued by the second defendant and the 30 days period given to the plaintiffs to demolish the religious house building ought to have complied with. Thus, the demolishing of the religious house building before the expiration of the 30 days period was inappropriate. The first and second defendants should have demolished the religious house after the expiration of the 30 days notice upon the failure of the plaintiffs to comply with the orders in the notice (see para $13(d)-(e))$.

(4) Exemplary damages were awarded to the plaintiffs based on the Court of Appeal's decision in Kerajaan Negeri Selangor \& Ors v Sagong bin Tasi \& Ors [2005] 6 MLJ 289 (see para $13(\mathrm{~h})$ ).
2. Robert Lee @ Robert Seet \& Anor v Wong Ah Yap \& Anor ${ }^{7}$

FEDERAL

COURT

(PUTRAJAYA)

ABDUL HAMID MOHAMAD, ARIFIN ZAKARIA AND AUGUSTINEPAUL FCJJ

CIVIL APPEAL NO 02-6 OF 2006(M)

11 May 2007

Equity -- Property, equitable interest in -- Fair and just -Statutory prohibition -- Factual change of ownership -- Whether courts may disregard statutory provisions to arrive at a decision -Malacca Lands Customary Rights Ordinance ss 3, 29

\section{Robert Lee @ Robert Seet \& Anor v Wong Ah Yap \& Anor ${ }^{8}$}

FEDERAL COURT (PUTRAJAYA)

\footnotetext{
${ }^{7}$ Malayan Law Journal Reports/2007/Volume 4/Robert Lee @ Robert Seet \& Anor v Wong Ah Yap \& Anor - [2007] 4 MLJ 393 - 11 May 2007

${ }^{8}$ Malayan Law Journal Reports/2007/Volume 4/Robert Lee @ Robert Seet \& Anor v Wong Ah Yap $\&$ Anor - [2007] 4 MLJ 393 - 11 May 2007
} 
ABDUL HAMID MOHAMAD, ARIFIN ZAKARIA AND

AUGUSTINEPAUL FCJJ

CIVIL APPEAL NO 02-6 OF 2006(M)

11 May 2007

Equity -- Property, equitable interest in

-- Fair and just -- Statutory prohibition

-- Factual change of ownership --

Whether courts may disregard statutory provisions to arrive at a decision -- Malacca Lands Customary Rights Ordinance ss 3, 29

Land Law -- Customary land -Transfer of right -- Restrictions in interest and transfer -- Property sold to unauthorized person -- Property acquired and compensation paid -Whether transfer valid and heirs entitled to compensation -- Malacca Lands Customary Rights Ordinance ss 3, 29

Li Keng Liat was the registered owner of land in Malacca which was subject to the provisions of the Malacca Lands Customary Rights Ordinance ('the Ordinance'). When he passed away in 1903, Lee Chim Giang was registered as the executor of his estate. In 1935, Tan Tai Tip, 'purchased' the said MCL land from Lee Chim Giang. Section 3 of the Ordinance provided that no transfer of any land subject to the Ordinance was valid unless such transfer was made either (a) to a Malay domiciled in Malacca; or (b) to a person issued with a certificate as qualified to hold such land. Section 29 of the Ordinance further provided that no sale of any interest in any such land was valid unless made in accordance with the Ordinance. Tan Tai Tip was neither a Malay nor a person issued with a certificate as qualified to own or to hold an interest in such land. Thus the land remained registered in the name of Lee Chim Giang, since deceased, as executor of the estate of Li Keng Liat. Tan Tai Tip and his kin entered into and remained in quiet and uninterrupted possession of the land, built houses and lived on the land, paid all quit rent and other dues, used the land for the planting of padi and vegetables and the rearing of cattle, and were in possession of the document of title to the land. There was no claim to the land by any beneficiary of Li Keng Liat. In 1981 the land was acquired by the State 
Director of Lands and Mines.

Following an inquiry compensation in the sum of RM616,146 was awarded to 'Li Chim Giang estate of Li Keng Liat' as 'owner' for the acquisition of the said land. Other smaller awards were made to some people, including a son of Tan Tai Tip, who were in possession of the said land, as 'persons interested' in the land. Administrators of the estate of Tan Tai Tip filed a suit against the defendants, the current executors of the estate of Li Keng Liat, deceased, claiming entitlement, as the owner, to the award of compensation. The trial judge gave judgment for the plaintiffs. The Court of Appeal dismissed the defendants' appeal and the defendants appealed to the Federal Court. Two questions were certified for the consideration of the Federal Court, namely: (1) when land under the Ordinance has been acquired,

4 MLJ 393 at 394

Does a prohibition in the Ordinance continue to apply to decide to whom compensation shall be paid?; and (2) can the doctrine of fairness be used to override the principles of law and the Ordinance?
Held, answering the first question in the affirmative and the second in the negative and allowing the defendants' appeal with costs:

(1) The trial judge allows respondents to rest their case on exclusive ownership. However, such compensation is for the 'owners' of the land is not for the invaders, which has in any case been compensated separately. So, this problem is actually about the 'owner'? The courts below seem to have missed this point (see para 13). The basis of the claim by the plaintiffs was that Tan Tai Tip had purchased the land. The plaintiffs could not extricate themselves from the alleged purchase as the basis of the right to the land which is now represented by the compensation money. To hold that the plaintiffs were entitled to the compensation was to recognize Tan Tai Tip's ownership right, which in turn 
meant recognizing the 'sale' (see para 46).

(2) The alleged sale took place in 1935. Money was paid and possession was given. No attempt whatsoever was made for Tan Tai Tip, not being a Malay, to be issued with a certificate qualifying him to hold the land. Thus sale could not be conditional. It is not necessary to consider whether s 3 of the Ordinance allows a conditional sale (see paras 40-41). The Court of Appeal was right that this was a case of an outright sale. This court had no difficulty accepting that there was a sale, but the question was whether the sale was valid or void (see paras 2021).

(3) The courts below supported the view that the right to compensation is a different matter entirely from the issue of land ownership. The argument that the property in the land could pass under an illegal contract, and therefore can not be applied would defeat the whole purpose of creation of customary land and Malay reserve land. This will give effect to the transaction which is clearly prohibited by law. It is wrong to think that this is a case of one-off payment of compensation and that it had no implications for the overall indigenous lands (see paras 42$43,45)$.

(4) Where, as here, the land subject to the law, sales made to people who are not eligible under this Act does not apply. The buyer does not become the owner of the land under the Ordinance and incompetent to acquire title to the land he bought. The alleged purchase by Tan Tai Tip (also he is not a Malay and not a certificated person) must be not considered legitimate (see paras 25, 30); Pang Cheng Lim v Bong Kim Teck \& Ors [1997] 4 AMR 3717 followed.

(5) Furthermore, the buyer can not be earned based on the Law, 
there is no other way by which the buyer can obtain it. To allow buyers to obtain a degree with a method that does not comply with the law, would defeat the purpose of the Ordinance. The Ordinance was enacted for the protection of certain classes of people. Cases on Malay reserve lands were also to the same effect. The fact that the land had been occupied by the others for a length of time did not extinguish the landholders title to the said lands.

4 MLJ 393 at 395

The Federal Court has answered the first question in the affirmative (see paras 26, 28, 32); Haji Hamid bin Ariffin v Ahmad bin Mahmud [1976] 2 MLJ 79 followed, Foo Say Lee v Ooi Heng Wai [1969] 1 MLJ 47 distinguished and Mistry Amar Singh v Kulubya [1963] 3 All ER 499 referred.

(6) Before applying the rules of English equity, the court must first ascertain whether there are written laws in Malaysia that the rules might conflict. Even if there is no such law, the application of these rules is subject to the condition that they should be applied only to the extent that circumstances allow and / or make necessary. Regulatory and legal Determination of Malay Reserve which are made with a definite purpose. There is no rule of equity (or common law) should be applied which would defeat the purpose, all leads to the effect of the application of fair rules, to give the effect of a valid transaction, must be stated by law. (see paras 52-53); Ramsden v Dyson (1866) LR1 HL129 distinguished and Devi v Francis [1969] 2 MLJ 169 referred.

(7) The decisions in the courts below were based on what was perceived as fair and just (see para 16). Here it was not just the issue of whether it would be more fair to decide in favor of the plaintiffs or the defendants. The court was faced with an 
illegal act by both of them, the result of which would cause at least one of them to suffer losses. The court had to deal with the acts of two persons that contravened the written law and which, if given effect to, would defeat the whole purpose of the written law (see para 58). The fact that the land had been acquired by the State made no difference. The land remained customary land until the State authority decides to declare it, or part of it, otherwise (see para 62).

(8) It is true that the court, through a decision, try to get the 'fair'. However, it can only be done within the confines of the law, not through some general and vague sense of justice and fairness. Our British colonial masters saw it necessary to make laws to protect the ownership of a class of persons over some areas of land. Laws were thus enacted as a matter of policy. These laws are preserved by the Constitution. If at all these laws need to be amended or repealed, this should, as a matter of policy, be done by the legislature, not by the courts through their decisions. This court thus answered the second question in the negative (see paras 60-63).

From the two cases above, we can see where the court in Malaysia prioritizes the rights of indigenous peoples, especially for customary land law which can be seen in Certificate 134 Akta Orang Asli 1954.

b. Indonesia's constotution in protecting their customary land law Indonesia is a country that has adopted a system owned by European countries which are based on so-called law of Roman Law, also known as the Civil system. The Civil Law had three characteristics, they are, a partial codification, the judge is not tied to the president, so the law becomes the principal law sources, and the judging system is inquisitorial. Inquisitorial means in that system the judges have bigger role in direct and decide the problems. The judges are finding the fact and accurate in assessing evidence. Judges in civil law are trying to get a 
complete picture of every event that is being faced since the beginning. It is different from a system that held by Malaysia, where the judges is given the broader power. In Indonesia, the judges cannot decide a case if there were no rule that arrange that case. This is closely related to the principle of legality. Thus, in Indonesia, to strengthen their customary land law, it would be needed the positive constitution that manages this first so that they have a strong binding legal power. In Indonesia there are constitutionally managing the customary land, from the recognition of human rights of indigenous peoples in Indonesia, began from article $18 \mathrm{~b}$ paragraph 2 Indonesian Constitution 1945, where in this article explained that the nation respect and confess the existence of indigenous people as long as it is not in contradiction with the principles of the Republic of Indonesia that is arranged in current law. With the arrangement of the constitution, private law also arranged it including: Law No. 51960 about Agrarian Basic Law (Peraturan dasar Pokok-pokok Agraria), Law No. 41 Year 1999 in accordance with Law No. 19, 2004 of Forestry (Pokok-pokok Kehutanan), Law No. 7, 2004 on Water Resources and many more that touched on indigenous peoples' rights protection. At the same time as protection for indigenous land can be seen in article 1 and 3 UUPA which acknowledgeof the confession on adat right as long as it is exists and true, as well as it is not in contradictory with the interest of the nation and state and the higher law. In addition, with the decision of Constitutional Court Number 35/PUUX/2012 on May 16, 2013, the Constitutional Court of Republic of Indonesia is reading the decision of Judicial Review of Law 41/1999 on Forestry on a proposition by AMAN (Aliansi Masyarakat Adat Nusantara/Alliance of Indigenous Peoples of the Archipelago) with two indigenous communities. In the decree No. 35/PUU-X/2012, the Constitutional Court emphasized that Indigenous Forest was forest that is located in the indigenous area, and no longer indigenous forest of the countries. Indigenous peoples in Indonesia welcomed the decision of 
the Constitutional Court by installing the board in their own ancestral lands. That plank said "indigeneous forest is no longer country forest. Indigeneous people carry out the Constitutional Court decision Number 35/PUU$\mathrm{X} / 2012$ concerning Indigenous Forest". In addition, the indigenous people also started rehabilitation movement in an indigenous area which is damaged by the company activities for the permission given by the state. ${ }^{8}$ From those explanations above, we now know that customary land in Indonesia is protected and respected similarly to customary law below them. Why do I call that because the customary land shall follow the rule of the local customary law because they are a united and cannot be differentiated.

\section{CONCLUSION}

Indonesia and Malaysia gave customary land the recognition of the law in their sovereignty territory which is shown in their constitution. The existence of Malaysia give substantial guarantees against the customary land law and can be seen from the presence of Undang-Undang Malaysia
Cetakan Semula Akta 134 Akta Orang Asli 1954 and with the decision of the judges, which prefer in indigenous peoples' side, if connected with the disputes over customary land, because they adopt the common law legal system; while the existence of Indonesia constitution which follows the civil law, providing the protection against the law of customary land by seeing article 18b paragraph 2 Indonesian Constitution 1945, the Law No. 5 Year 1960 regarding laws to Basic Agrarian, Law No. 41 In 1999 in accordance with Law No. 19, 2004 of Forestry, the Act No.7/2004 on Water Resources, which specified in article 1 and 3 UUPA in 1960, and the decision Constitutional Court Number 35/PUUX/2012 on May 16, 2013.

\section{REFERENCES}

\section{Book}

B Hooker. M, 1970, Readings in Malay Adat Laws, Singapore University Pers, Singapore.

B Hooker. M, 1972, Adat Law in Modern Malaya Land Tenure, Traditional Government and Religion, Oxford University Press, London.

B Hooker. M, 1980, Native Law in Sabah and Sarawak, Malayan Law Journal, Singapore.

Cornelis Van Vollenhoven, 1983. Orientation on Indonesian Customs, 
in cooperation with Inkultra

Foundation inc., Jakarta

Hardjito Notopuro, 1969, "About Adat Law, Definition and Limitation in National Law", National Law Magazine No. 4, Jakarta

Ridwan Ahmad Fauzie, 1982, Hukum Tanah Adat Multi Disiplin Pemberdayaan Pancasila, Dewaruci Press, Jakarta.

Soerojo Wignojodipoero, 1983. Introduction and Principles of Adat Law, Haji Masagung, Jakarta.

Wilkie Margaret, Peter Luxton, Rosalind Malcolm, 2003, Land Law 20032004 (Blacstone's Law $Q$ \& A), Oxford University, London.

Wulansari C. Dewi, 2012. Adat Law Indonesia An Introduction. ReflikaAditama,Bandung

\section{Journal}

Malayan Law Journal Reports/2007/Volume 4/Robert Lee @ Robert Seet \& Anor v Wong Ah Yap \& Anor - [2007] 4 MLJ 393 - 11 May 2007

Malayan Law Journal Reports/2010/Volume 5/Pedik bin Busu dan lain-lain lwn Yang Dipertua Majlis Daerah Gua Musang dan lain-lain - [2010] 5 MLJ 849 - 29 October 2009. 